DOI : 10.24260/khatulistiwa.v8i2.1249

\title{
KHITANAN ON PONTIANAK MALAY SOCIETY, WEST KALIMANTAN
}

\author{
Sella Dwi Pratiwi \\ Pontianak State of Islamic Studies (IAIN) \\ Email: selladwipratiwi8@gmail.com
}

\section{HIGHLIGHT}

- $\quad$ - Malay Khitanan (circumcision)

- $\quad$ - Islam and Local Culture

- - Pontianak Malay

- - Coastal of West Kalimantan

\begin{tabular}{lll}
\multicolumn{2}{l}{ ARTICLE HISTORY } \\
& $:$ & 10 July 2018 \\
Submitt & & \\
Revision & $:$ & 15 July 2018 \\
Revision & $:$ & 10 August \\
Minor & & 2018 \\
& $:$ & 20 August \\
Accepted & & 2018 \\
Published & $:$ & 2 September \\
& & 2018
\end{tabular}

KHATULISTIWA: Journal of Islamic Studies Vol. 8, No. 2. September 2018

\begin{abstract}
Indonesia has a wide variety of ethnic groups, customs and cultures. One of the interesting cultures is the culture of Khitanan (circumcision) of Pontianak Malay society, West Kalimantan. This article will describe Khitanan culture in Pontianak Malay society to describe the diversity of national culture. Data obtained through interviews and observations in Pontianak. Shows that Khitanan is practiced for baby girls and boys. Khitanan or circumcision is the Islamic Shari'a which becomes sunnah of Prophet Mohammed. Become a requirement for one's perfection in worshiping Allah SWT. For a baby girl it is usually done when the baby is new baby born or at 40 days old by a midwife. For boys they will be circumcised when the age of 8 to 12 years and it is carried out by a mantri (traditional doctor) or doctor. Before boys are circumcised, there are several processions that must
\end{abstract}

DOI: 10.24260/khatulistiwa.v8i2.1249

Khitanan on Pontianak Malay Society, West

Kalimantan 
Keyword:

be carried out first. Circumcised children also face taboos that should not be violated. After the boy was circumcised, besanji was carried out and the recitation of selamat prayer had been given fluency in carrying out the Shari'a required by religion. The host invites neighbors and families. The food provided is the same at the marriage reception; the difference is when a marriage reception arrange on the tables but in Khitanan event, the food will be arranged on the carpets. Besanji ended the traditional procession of Khitanan culture in Pontianak. This description shows that Pontianak Malay tribe considered Khitanan is important. The procession and series also show differences with Khitanan culture in other regions.

Local Culture, Khitanan (Circumcision), Malay Ethnic, Pontianak Malay.

C2018 Khatulistiwa All Rights Reserved

KHATULISTIWA: Journal of Islamic Studies Vol. 8, No. 2. September 2018
DOI: 10.24260/khatulistiwa.v8i2.1249

Khitanan on Pontianak Malay Society, West Kalimantan 


\section{A. INTRODUCTION}

Indonesia has many islands, one of them is Kalimantan island. This island is the five largest islands in Indonesia. Kalimantan has five provinces, namely the provinces of West Kalimantan, East Kalimantan, South Kalimantan, Central Kalimantan, and North Kalimantan.

Each place within the province has many various of ethnic groups, customs and cultures. For example, in West Kalimantan it is known to have several people's cultures: gawai, carbide cannons, notokng, naek tojang, etc. (see Yusriadi, 2018).

One of the most interesting customs and cultures in West Kalimantan especially the city of Pontianak, is a culture of Khitanan (circumcision). Khitanan is cutting the skin covering the head or tip of the men genitals and cutting the upper part of the women genitals. The goal is to keep the genitals from collecting dirt. In addition, among the people, Khitanan is also considered by some as a way to urinate freely.

Khitanan is a sunnah that must be done for boys and girls. It is because khitan is one of the teachings of Islam to be the difference between Muslims and Christians. (Rasyid, 1990).

Based on shahih opinion stated that khitanan is something good; some consider it is a sunnah and some consider it is an obligation (Hakim, 2017: 139). Furthermore, there are some opinions about when khitanan must be done. Some say as soon as possible after birth, and some say it should be done at certain ages. (Hakim, 2017: 139-141).

Khitanan does not cause a negative thing from the medical side - although there are some people consider this cultural activity in a particular community of girls to be considered "sadistic" and dangerous (Mustaqim, M, 2016). In fact, in many researches and reviews about this culture, khitanan is considered as a form of knowledge and wisdom of the community about how to maintain reproductive health.

A child can be circumcised if he is willing or able to do so. Someone who has been baligh must be ready to be circumcised, and if he is reluctant, parents usually force him including persuading him to be circumcised.

Khitanan (circumcision) is also carried out if there is a non-Muslim religion wants to enter Islam (converts). Among Malays in West Kalimantan, including Pontianak, khitanan is

KHATULISTIWA: Journal of Islamic Studies Vol. 8, No. 2. September 2018
DOI: 10.24260/khatulistiwa.v8i2.1249

Khitanan on Pontianak Malay Society, West

Kalimantan 
one sign that a person is Muslim and Malay. People who are not circumcised are socially bad and considered not qualified yet as Muslims. (Yusriadi, 2005). Moreless the same situation was found in Banjar community in South Kalimantan. Khitanan is an important part that must be carried out. (Nurdiyana, 2010: 116).

Khitanan is a part of religious order. There is a combination with local culture in its implementation. This article will describe how the combination of Islam and local culture in the culture of khitanan in Malay community of Pontianak West Kalimantan.

\section{B. METHOD}

This research is about the culture of khitanan or circumcision in Malay society in Pontianak. This research approach is qualitative and based on field studies. Data was obtained through interviews with a number of informants in Pontianak who are be able to provide the information needed to answer the research questions.

The research questions in this study is how the form of khitanan culture in Pontianak Malay society, how this cultural procession, what equipment must be prepared, who was involved, and how this cultural distinctiveness compared to culture in other societies. The researchers interviewed a religious leader, a mother involved in khitanan activities, and two children who had been circumcised. In addition, researchers also use comparative data from journals obtained through various sources regarding khitanan activities of Malays.

The researcher chose to explore this study because researcher wanted to introduce Malay culture in Pontianak and it is the researcher's obligation to continue and preserve this culture especially Malay culture in Pontianak. This culture is very interesting eventhough khitanan can be found in other regions but there is one procession as the characteristic of Pontianak Malay culture. The benefits of this research are to persuade readers in continuing to preserve the culture inherited from ancestors.

KHATULISTIWA: Journal of Islamic Studies Vol. 8, No. 2. September 2018
DOI: 10.24260/khatulistiwa.v8i2.1249

Khitanan on Pontianak Malay Society, West

Kalimantan 


\section{RESULT AND DISCUSSION}

\section{General Description of Pontianak City}

Pontianak is the provincial capital of West Kalimantan. The city of Pontianak is now traversed by two important icons, namely the equator or the midline of the earth; and the Kapuas River, the longest river in Indonesia. These two icons affect the development of Pontianak city today.

As a center of government and economy, Pontianak city is visited by many people to conduct some social affairs, administrative affairs at the provincial level, adequate tertiary education and finding a lot of necessities so they must go to Pontianak. Therefore, Pontianak is the center of West Kalimantan people activities from many regions.

Many people go to Pontianak to conduct their affairs. They only stay on their affairs or directly return to their region. Some others choose to stay and even settle in this city. The migration of people from villages to Pontianak is a common phenomenon for a developing city. (See Hasanudin, 2014; Minza, WM, 2012; Yusriadi, Ed. 2015).

The arrival of new comers to Pontianak city caused Pontianak becomes a bustling and heterogeneous city. The population reaches more than 664 thousand (dukcapil, 2018).

From religious side, Pontianak also has religious practices: Islam, Christianity, Catholicism, Confucianism, Hinduism and Buddhism. From the tribal side, Pontianak has various tribes, namely: ethnic Malays, Bugis, Dayaks, Chinese and immigrant tribes such as Javanese, Madurese, and so on.

Although there is no valid data on their existence, however, in general the existence of these tribes can be seen in the community. Understandably, the awareness or sensitivity of Pontianak people particularly and West Kalimantan generally regarding ethnicity is very strong.

Malays in Pontianak are the majority tribe. A glance, their numbers are more than others. Malays and their culture are also dominant in Pontianak. They are known to be very thick with ancestral traditions to show inheritance from ancestors. (Yusriadi, Ed. 2015).

KHATULISTIWA: Journal of Islamic Studies Vol. 8, No. 2. September 2018
DOI: 10.24260/khatulistiwa.v8i2.1249

Khitanan on Pontianak Malay Society, West

Kalimantan 


\section{Pontianak Malay Khitanan (Circumcision) Culture}

Sunatan/khitanan (circumcision) is one of Malay cultures in Pontianak city. This culture is carried out by all Malays with different ways of implementing it.

Among Malays, this culture is actually associated with Islamic law. Khitanan became the sunna of Prophet Muhammad. (Hakim, 2017). Boys who have reached the age of baligh must do so. This is a requirement for one's perfection in worshiping Allah.

Khitanan culture in Pontianak Malay society is divided in two. First, khitan for girls. The execution of khitan on girls was carried out when the girls are new baby born. Usually Pontianak Malays circumcised their daughters when they were 40 days old and it is done by a midwife.

In the past, khitanan was done by traditional midwife. Usually people called her , mokteh jare as the expert at circumcising. Nowadays it has been done by a midwife or doctor because of the fear of dangers that will be occurred. The Malays will pierce their daughter's ears when they are circumcised, so that their daughters feel the pain only once. It is not uncommon for girls to be pierced when they are one or two years old.

After their daughters circumcised, the parents will hold syukuran/selamatan for the baby. syukuran/selamatan is carried out with simply. syukuran/selamatan for girls usually only invites neighbors and only known by the family itself. Before a reception or event, the family calls their neighbors to ask for help to cook and wash the disher. In some places, people who expert and capable are asked by the family to help while the others help to make the work easier. It shows that the othera participate in the culture.

Khitanan for boys. Unlike girls, khitanan for boys is carried out by considering the time and money. A boy is usually considered ready to be circumcised when they are eight to twelve years old. Comparing with girls that only 40 days old, it because the eight years old boys are considered stronger or better prepared when circumcised. Circumcising before those ages, it will be considered severe for the boys and also for the parents in taking care their boys.

Nowadays, khitan for girls are done by doctor like khitan for boys. For certain communities, circumcising for their children are handed over to a doctor. In other

KHATULISTIWA: Journal of Islamic Studies Vol. 8, No. 2. September 2018
DOI: 10.24260/khatulistiwa.v8i2.1249

Khitanan on Pontianak Malay Society, West

Kalimantan 
communities, circumcising was handed over to mantri (traditional doctor). For this reason, occasionally in the middle of Malay community in Pontianak there are mass khitanan activities organized by certain organizations or institutions. This mass khitanan is aimed to help the children who are underfunded for carried out khitan.

Khitan for boys is an opportunity for families to show others about their child's status. Circumcised children will soon be considered as children who will enter the adult phase. In fact, according to the informant, some consider that circumcised children are considered as adults.

Relating with this process, children who are not circumcised are regarded as dishonor and disgrace. For a long time, children who are not willing to be circumcise will be dishonored and disgraced by community. In contrary, children who are willing to be circumcised will be being proud of them also get praise and prizes by them. Gifts or gratitudes in the form of money, sarongs, koko clothes, and usually some food.

For wealthy families and families that having many rizq, they circumcised their children by having some parties. In the party, the families invite guests, friends, parents and family colleagues. The family provides various types of food to entertain guests.

The food provided by the host is usually complete meals, such as rice, soy sauce chicken, vegetable soup, crackers, tuna, chili sauce, cakes, and mineral water. Usually cakes are served or given to guests, namely keroket, resoles, agar-agar, and blodar cakes. So far, there are no special cakes that appear in the event.

A tent was set up for organizing this event so the event became more comfortable. This tent is an additional place for having meals and sit for guests while attending the reception.

Usually circumcised children receive guests and prepare to receive donations from the guests. For big events like this, the host prepare a particular place for guests to put their envelopes. The money in the envelopes are vary between twenty thousand, fifty thousand, to one hundred thousand rupiahs.

The circumcised boys are considered as the brides. Means that the implementation, the people involved, the work and costs spent for this event is the same as carrying a marriage party.

KHATULISTIWA: Journal of Islamic Studies

Vol. 8, No. 2. September 2018
DOI: 10.24260/khatulistiwa.v8i2.1249

Khitanan on Pontianak Malay Society, West

Kalimantan 
Meanwhile for people who unable to carry out this event or those who have other considerations can carry out a simple selamatan. Reading selamat prayer is read by the local religious leader, attended by some of the relatives, also prepared some food and dishes.

Before boys are circumcised, there is Buang-buang ritual that must be carried out first. Buang-buang ritual is a procession carried out to protect children and families from disturbing or supernatural spirits.

Buang buang ritual is equipped with sesajen (offerings) in a plain white plate. On this plate are put a yellow material, berteh puteh, yellow rice, and chicken eggs. Those items will be dumped or washed away in the river or ditch. Pontianak Malays believe that if they are dumped or washed away into the river, evil or bad luck will drift away following the water flow and never return again.

After Buang-buang ritual was carried out the circumcised children were paraded around the village accompanied by tanjidor and reading salawat for the Prophet Muhammad. In the parade, the people or families bring pokok telok (boiled egg) and manggar (coconut flowers) distributed to invited guests or small children.

When being paraded, the boy dressed in telok belange, a typical Malay clothing of Pontianak. After completing the parade, the child will be given tolak bala' drink. This water is provided by a local figure or elder. It is intended to the circumcised child when they are carrying khitan, they will be safe, not in danger and running smoothly. The danger that Malays fear is the infection in the wounds.

Beside asking for help from a traditional doctor, parents also invite religious leaders and communities to pray and protect the safety of circumcised children. Therefore, after khitan and reception activities, barzanji readings and selamat prayers were also carried out. This activity involves neighborhood and family neighbors. Besanji ended the traditional procession of khitanan culture in Pontianak West Kalimantan especially Pontianak Malay tribe.

In the view of Pontianak Malay society, safety disturbances of circumcised children can come from disturbances of supernatural and invisible spirits. Beside drinking tolak bala' water, barzanji readings, and prayers, the community also tries the prevention so that children do not experience an excessive pain in the wounds.

KHATULISTIWA: Journal of Islamic Studies

Vol. 8, No. 2. September 2018
DOI: 10.24260/khatulistiwa.v8i2.1249

Khitanan on Pontianak Malay Society, West

Kalimantan 
Circumcised children usually lie down with bandage on the tip of genital. They do not wear pants or sunnah inwearing sarong. To make sarong can not touch the tip of the genitals, Malays installed a protector from bakol or a basket that was placed over the genitals. Then sarong is tied to a rope and hung on the ceiling.

The circumcised child has some prohibition such as forbidden to eat some food that caused an itchy effect like eggs, shrimp, chicken and so on. The child is also forbidden to step over chicken droppings (the type of lancong chicken) because Malays believe that when they are disobeyed, the child's genitals will not recover and even infected. Other prohibitions are also not allowed to climb trees and running a lot.

Besides in this situation, a circumcised boy is privileged. They get more attention and service after being circumcised until the wound is stated dry by mantri or doctor.

Islam and Sunatan Culture of Pontianak Malay

Sunatan of Pontianak Malay shows an assimilation of local culture and Islam. From the elements of local culture, we can see in the procession of circumcised children, receptions or parties after sunatan on a large scale, prohibition must be obeyed by families and circumcised children, and buang-buang or giving sesajen for supernatural spirits so that they will not disturb the circumcised children or interfere the process of the procession.

Local elements can also be seen from the people ways to protect the circumcised children from illness after khitan. The community gives or puts baskets on the genitals as a way to make the bandaged genital tip untouched by sarong or other objects. Thus, the wound is safe and protected.

Cultural elements are also seen in terms of food preparation and social system of this activity. The community has many options in organizing activities in accordance with their abilities. Those who are able to choose to carry out a single sunatan and reception at the same time, while those who are not able to choose to carry out a single sunatan, they can carry out mass sunatan and prayer with a simple food preparation. Behind these options, there are always social consequences they receive. Sunatan bride, a term for large receptions for circumcised children, shows how luxurious this activity in the terms of social system.

KHATULISTIWA: Journal of Islamic Studies

Vol. 8, No. 2. September 2018
DOI: 10.24260/khatulistiwa.v8i2.1249

Khitanan on Pontianak Malay Society, West

Kalimantan 
In terms of Islam, we can see that khitanan is associated with the beliefs of Malay people as Muslims. Sunatan - especially male circumcision, is believed to be part of a religious order that must be carried out. This is a marker of those who are considered to distinguish them from other religions. Even though non-Muslims today are circumcised, however, this belief is still firmly embedded in people's minds.

Moreover, in the procession of khitanan was filled with several activities that reflected them as Islam. For example, there are recitations of selawatan and besanji. As Muslims, they also appear in clothes that characterize Muslims - men wearing a cap and sometimes sarong, while a woman wear a veil.

The assimilation of local culture and Islam in sunatan activities in Malay communities in Pontianak is inseparable. At least, so far, both have been a complete assimilation in this culture. That is the characteristic of sunatan in Pontianak Malay society which may not be the same as sunatan culture in other communities.

\section{CONCLUSION}

Pontianak Malays have different ways in sunatan. Several processions carried out made different cultures of sunatan in other regions. Sunatan for girls is done when the baby is new baby born. Pontianak Malays usually circumcise their daughters when they are 40 days old by a midwife. In the past, sunatan was carried out by a traditional midwife, called mokteh jare who expert in circumcising, but now it has been done by midwives or doctors because of fear of the dangers that will be occurred.

For boys they will circumcise when they are eigth to twelve years old. In my village, boys are mostly circumcised at the age of twelve years old. Pontianak Malay people will conduct sunatan when the reception has been carried out. The food provided by the host is usually complete rice such as rice, soy sauce chicken, vegetable soup, crackers, tuna, chili sauce, cakes, and aqua water. Cakes served or given to guests are keroket, resoles, gelatin, and blodar cakes. The child also must obey the prohibition such as do not eating food which will cause itchy effects such as eggs, shrimp, chicken and so on.

Children are also prohibited to step over chicken droppings (the type of lancong chicken) because Malays believe that when they are disobeyed, the child's genitals will not

KHATULISTIWA: Journal of Islamic Studies

Vol. 8, No. 2. September 2018
DOI: 10.24260/khatulistiwa.v8i2.1249

Khitanan on Pontianak Malay Society, West

Kalimantan 
recover and even infected. Other prohibitions are also not allowed to climb trees and running. After the boy was circumcised, he made besanji, namely the recitation of selamat prayer because they can carry out Shari'a required by religion well. Besanji ends the traditional procession of sunatan culture in Pontianak West Kalimantan especially Pontianak Malay tribe.

KHATULISTIWA: Journal of Islamic Studies

Vol. 8, No. 2. September 2018
DOI: 10.24260/khatulistiwa.v8i2.1249

Khitanan on Pontianak Malay Society, West Kalimantan 


\section{BIBLIOGRAPHY}

Disdukcapil. (2018). Data Jumlah Penduduk Semester I 2018, Penduduk Pontianak Capai 664.394 Jiwa. Dalam https://disdukcapil.pontianakkota.go.id. 29 Agustus 2018.

Hakim, Lukman. (2017). Khitan Perempuan dalam Perspektif Hukum Islam. Ar-Risalah Vol XV No. 1: 138-140.

Minza, WM. (2012).Young Migrants and education-to-work transitions in Pontianak, West Kalimantan. The Asia Pacific Journal of Antrhropology 13 (1): 64-75.

Mustaqim, M. (2016). Konstruksi dan Reproduksi Budaya Khitan Perempuan; Pergulatan antara Tradisi, Keberagamaan dan Kekerasan Seksual di Jawa. Palastren Vol. 6 (1): 89106.

Nurdiyana, T. (2010). Sunat Perempuan pada Masyarakat Banjar di Kota Banjarmasin. Komunitas 2 (2): 116-124.

Rasyid, Sulaiman, (1990). Fiqh Islam Lengkap. Jakarta: At-Thahiriyah

Yusriadi, Ed. (2015). Pernak-pernik Melayu Pontianak. Pontianak: STAIN Pontianak Press.

KHATULISTIWA: Journal of Islamic Studies

Vol. 8, No. 2. September 2018
DOI: 10.24260/khatulistiwa.v8i2.1249

Khitanan on Pontianak Malay Society, West

Kalimantan 